\title{
A Blended Professional Development Program to Help a Teacher Learn to Provide One-to- One Scaffolding
}

Problem-based learning (PBL) has been increasingly used in K-12 settings due to its potential to promote deep content knowledge, self-directed learning ability, and problem solving ability among K-12 and post-secondary students (Belland, French, \& Ertmer, 2009; Bérci, 2012; Hmelo-Silver, 2004; Tan, 2003). To help students succeed in PBL, teachers need to provide oneto-one scaffolding, defined as support that allows students to complete tasks that are beyond their unassisted abilities, and which is customized according to dynamic assessment (Belland, 2014; Schmidt, Rotgans, \& Yew, 2011; van de Pol, Volman, \& Beishuizen, 2010; Wood, Bruner, \& Ross, 1976). In this exploratory study, we examine the provision of one-to-one scaffolding by a middle school teacher who underwent blended professional development on the instructional approach. We aim to gather preliminary evidence on whether blended, asynchronous professional development informed by the professional development literature has the potential to impact teachers' provision of one-to-one scaffolding, and, if so, how. This is important in that evaluations should focus on the impact of target interventions on behaviors (Gamble, 2008;

Kaufman, Keller, \& Watkins, 1996).

\section{Literature Review}

\section{Problem-based Learning}

In PBL, students work in small groups to address authentic, ill-structured problems (Barrows \& Tamblyn, 1980; Hmelo-Silver, 2004). Such problems (a) cannot be solved by applying a simple procedure, and (b) have multiple solutions and solution paths (Jonassen, 2000). To address PBL problems, students need to (a) determine what they know about the problem and what they need to investigate further and how, (b) find and interpret new 
information, and (c) develop and defend a feasible solution (Belland, Glazewski, \& Richardson, 2008; Hmelo-Silver, 2004). To be successful in PBL, students need to (a) direct their own learning (Hung, 2011; Loyens, Magda, \& Rikers, 2008) and (b) engage in effective group work (Belland, Glazewski, \& Ertmer, 2009; Dolmans \& Schmidt, 2006; Lindblom-Ylänne, Pihlajamäki, \& Kotkas, 2003; Lohman \& Finkelstein, 2000).

Problem-based learning in science. To foster higher-order thinking outcomes and engagement, many have proposed that science instruction be centered on authentic scientific problems (Abd-El-Khalick, 2012; Kolodner et al., 2003). Such problems include socio-scientific issues - authentic problems that require scientific and social considerations (Sadler, Barab, \& Scott, 2007; Smith \& Gillespie, 2007; Webster-Wright, 2009). For example, a socio-scientific issue may involve whether it is right to genetically engineer crops that are resistant to pests, or what should be done to optimize the water quality in a local river. Because socio-scientific issues have no one right answer, solutions are judged based on their evidential support (Abi-El-Mona \& Abd $\square$ El $\square$ Khalick, 2011; Sadler \& Donnelly, 2006). But K-12 students struggle creating and evaluating arguments (Belland et al., 2008; Bricker \& Bell, 2008; Osborne, 2010).

Role of teachers in problem-based learning. PBL requires one-to-one scaffolding contingent support provided to individual students that allows them to perform tasks that are beyond their unassisted abilities, such as solving problems or creating evidence-based arguments (Belland, 2012; Hmelo-Silver \& Barrows, 2006; Wood et al., 1976). One-to-one scaffolding employs (1) the following strategies “(a) enlisting student interest, (b) controlling frustration, (c) providing feedback, (d) indicating important task/problem elements to consider, (e) modeling expert processes, and (f) questioning" (Belland, 2014, p. 507), and (2) continual diagnosis of student skill, customization, and withdrawal of support (Hogan \& Pressley, 1997; van de Pol et 
al., 2010). To enlist interest, elementary school teachers asked cognitively challenging questions (Lutz, Guthrie, \& Davis, 2006). As an example of controlling frustration scaffolding, when sensing that students were frustrated, a science teacher reassured students that uncertainty was natural and not caused by a lack of prior knowledge, and provided a metaphor to which students could relate (Rosiek, 2003). An elementary teacher provided feedback scaffolding by confronting discrepancies in student thinking (Gillies \& Boyle, 2006). To indicate important task elements to consider, an elementary school teacher asked open-ended questions to guide students in the direction of important problem aspects to consider (Gillies \& Boyle, 2006). As an example of modeling expert processes, middle school teachers modeled problem-solving strategies when they sensed that the strategies students were using were not productive (Raphael, Pressley, \& Mohan, 2008). A third grade reading teacher employed questioning scaffolding by asking questions to encourage students to consider readings from other perspectives; this helped the students be critical readers (Maloch, 2002).

Based on continual diagnosis, teachers can customize one-to-one scaffolding based on three types of contingency:

- Instructional contingency - how to support activity

- Domain contingency - what to focus on next [e.g., content to be covered next, strategies to model, etc.]

- Temporal contingency - if and when to intervene (Wood, 2003, p. 14)

Also crucial is the idea of intersubjectivity, in that students and teachers need to have a shared understanding of the instructional goal (Wood et al., 1976). This in turn increases the likelihood that the student will be able to complete the formerly scaffolded task alone.

It has long been known that tailoring instruction to the individual needs of students leads to big learning gains. For example, one-to-one tutoring led elementary students with low reading skills to perform 0.41 SDs better than their control counterparts (Elbaum, Vaughn, \& Hughes, 
2000). A meta-analysis that covered a wider range of participants found that one-to-one tutoring led experimental students to perform 0.40 SDs better than control students (P. A. Cohen, Kulik, \& Kulik, 1982), medium effect sizes under Cohen’s guidelines (J. Cohen, 1969). However, many covered one-to-one tutoring programs involved direct instruction. Such interventions covered one part of the one-to-one scaffolding definition - that support be provided on a contingent basis. But they did not cover the other - that the support consist of questions, prompts, and modeling that builds off of what students know to enable them to construct knowledge themselves.

A recent meta-analysis indicated that one-to-one scaffolding led experimental students to perform on average 0.79 standard deviations better than control students (VanLehn, 2011) - a large effect according to Cohen's guidelines (J. Cohen, 1969). Ruiz-Primo and Furtak (2006) found that the provision of one-to-one scaffolding is a better predictor of student gain scores than pretest scores. Frey and Fisher (2010) observed 18 elementary teachers recognized by their districts for high student achievement. These teachers used questioning (e.g., for elaboration), prompting such things as reflection, and modeling extensively in small group learning activities (Frey \& Fisher, 2010). This led to students' active interpretation of the content (Frey \& Fisher, 2010). Highly engaging middle school teachers covered more content at a deeper level than lowengaging teachers, and were found to engage in one-to-one scaffolding more than the latter (Raphael et al., 2008). The use of one-to-one scaffolding or the lack thereof can lead to high or low engagement, respectively (Lutz et al., 2006).

One-to-one scaffolding is not often used (Lockhorst, Wubbels, \& van Oers, 2010; Myhill \& Warren, 2005; Oliveira, 2010; van de Pol, Volman, \& Beishuizen, 2012). One reason may be that many teachers struggle to conduct the required continual diagnosis (Graesser, D’Mello, \& Cade, 2009). Continual diagnosis is challenging because students often (a) do not respond 
accurately to questions about whether they understand, (b) do not have shared understanding of ideas being discussed, and (c) mistakenly appear to understand (Graesser et al., 2009).

van de Pol, Volman, and Beishuizen (2011) described the provision of one-to-one scaffolding by three social studies teachers in a middle school focused on "supporting autonomous student learning” (p. 48). Twenty percent, 50\%, and 50\%, respectively, of each teacher's interactions consisted of whole class interaction. Of the remaining subject matterrelated interactions, $36 \%, 50 \%$, and $28 \%$, respectively, were contingent scaffolding. RaskuPuttonen, Eteläpelto, Arvaja, and Häkkinen (2003) studied two secondary school history teachers who worked to facilitate project-based learning. The teacher who saw his role as a guide provided more scaffolding than the teacher who saw his role as a controller.

One-to-one scaffolding can be supplemented with computer-based scaffolding, which can fill many of the same roles but is not dynamic because it is designed based on anticipated student needs (Belland, 2014; Quintana et al., 2004; Reiser, 2004).

\section{The Development of Pedagogical Content Knowledge}

The ability to engage in one-to-one scaffolding can be seen as a form of pedagogical content knowledge - knowledge of representations of and effective ways to help students learn particular content (Shulman, 1986). Pedagogical content knowledge such as the ability to contingently respond to student performance characteristics often develops and is deployed at different times (Grossman, Hammerness, \& McDonald, 2009; Monte-Sano \& Budano, 2013).

\section{Professional Development}

Professional development is a key strategy to help teachers develop pedagogical content knowledge (Van Driel, Beijaard, \& Verloop, 2001). However, much current professional development is not conducive to teacher learning. Despite advances in theory about professional 
development, most professional development continues to be decontextualized and delivered in a didactic manner (Webster-Wright, 2009). Typically, professional development consists of oneshot workshops in which teachers are pulled out of class for an in-service day, and university faculty or other personnel lecture to them about an educational technique (Wayne, Yoon, Zhu, Cronen, \& Garet, 2008; Webster-Wright, 2009). When professional development is separated from work contexts (e.g., K-12 classrooms), it is often unclear how the new instructional approaches can be applied. Furthermore, by providing professional development didactically, teacher educators perpetuate the (false) dichotomy between what one learns in school and what one does in real life (Webster-Wright, 2009). In short, traditional professional development does little to (a) change K-12 teachers' practices, or (b) increase student learning (Brand \& Moore, 2011; Smith \& Gillespie, 2007; Yoon, Duncan, Lee, Scarloss, \& Shapley, 2007). If teachers change at all through traditional professional development, they often only implement a few covered strategies within their existing instructional approaches (Smith \& Gillespie, 2007).

There are two primary theoretical bases of traditional professional development: stage theory and an update approach. According to stage theory, teacher professional competence can be represented by defined stages, and professional development needs to provide the knowledge that will allow teachers to move to the next stage (Dall'Alba \& Sandberg, 2006). In the "update" approach, teachers' existing knowledge about teaching is considered outdated and needs to be replaced (Gerard, Varma, Corliss, \& Linn, 2011; Webster-Wright, 2009). Both such theoretical bases are problematic, but for different reasons. The stage theory assumes that skill development is "an accumulation of a defined body of knowledge and skills" (Dall'Alba \& Sandberg, 2006, p. 386). However, teacher knowledge and skills develop and are applied in a dynamic, non-linear manner (Clarke \& Hollingsworth, 2002; Dall’Alba \& Sandberg, 2006; Fessler \& Rice, 2010). 
Following an update approach ignores teachers' practical knowledge about teaching in general and the socio-cultural context of the school. Professional development efforts that ignore or aim to replace frameworks teachers develop through experience (Van Driel et al., 2001) or ignore the cultural context of individual schools (Opfer \& Pedder, 2011) will not likely be successful.

\section{Characteristics of Effective Professional Development}

Duration. Professional development may take 1 year or more to impact teaching practice (Gerard et al., 2011). Professional development that averaged 53 contact hours spread over 4 to 12 months raised student performance on average 21 percentile points (Yoon et al., 2007). All programs with more than 14 contact hours had positive effects on student achievement, while no program with 14 contact hours or less had a positive effect (Yoon et al., 2007).

Context. Teacher skills need to be taught in context (Belland, 2009; Dall'Alba \& Sandberg, 2006; Timperley \& Alton-Lee, 2008; Webster-Wright, 2009). For example, professional development should provide examples of the instructional strategies deployed in similar classrooms to those of the recipients. It is also important to consider the context in which the target skills of the professional development will be used, including school culture and teacher views and dispositions (Webster-Wright, 2009).

What teachers do with content during professional development. To be effective, professional development needs to elicit ideas from teachers (Clarke \& Hollingsworth, 2002; Gerard et al., 2011). This can include brainstorming and predicting the results of actions, and enactment of new ideas into their curricula. This may help teachers connect what they are learning to their existing teaching knowledge.

To integrate new ideas into professional practices, teachers should critically evaluate where new knowledge fits within their existing teaching schemas (Brand \& Moore, 2011; 
Dall'Alba \& Sandberg, 2006; Lawless \& Pellegrino, 2007; Opfer \& Pedder, 2011). For example, if teachers are learning for the first time how to facilitate PBL, and have implemented some problem solving activities before, they need to think critically about where PBL departs from and intersects with the activities they did in the past. In doing so, they can see how knowledge gained during their prior experiences can inform and be transformed by the new knowledge.

Extent to which peer learning is encouraged. Peer collaboration contributes much to the success of professional development (Lawless \& Pellegrino, 2007). Peer collaboration targeted at instructional planning can be effective in ensuring application of the target knowledge and skills (Dede, Jass Ketelhut, Whitehouse, Breit, \& McCloskey, 2008; Mouza, 2009).

\section{Professional Development on Scaffolding}

van de Pol et al. (2012) studied 4 teachers at 2 middle schools who underwent professional development on scaffolding. The teachers began the term providing little one-to-one scaffolding. After professional development, their use of one-to-one scaffolding increased, but this did not hold steady throughout the school year. Lutz, Guthrie, and Davis (2006) studied two fourth grade teachers who attended professional development on scaffolding for integrated reading/ science instruction. They found that the teachers' provision of one-to-one scaffolding decreased as the unit progressed. Elementary teachers who underwent professional development on scaffolding English Language Learners provided higher quality scaffolding in the second semester after receiving professional development than in the first semester (Hart \& Lee, 2003).

\section{Blended Professional Development}

All reviewed professional development programs for one-to-one scaffolding consisted of face-to-face workshops and small group activities. Basing professional development on only face-to-face activities limits scalability and sustainability, important considerations in 
maximizing the impact of grant funding (Dede et al., 2008; Holmes, Polhemus, \& Jennings, 2005). One way to improve scalability and sustainability may be to follow a blended learning approach. Blended learning is an instructional approach that combines face-to-face experiences with online learning activities (Cooner, 2010; Owston, Wideman, Murphy, \& Lupshenyuk, 2008). Blended learning can fit into teachers' busy schedules (Owston et al., 2008). By incorporating online learning activities, professional development can give teachers access to larger communities of practice (Dede et al., 2008; Lock, 2006). With blended professional development, teachers can apply techniques in their classrooms as they are learning (Owston et al., 2008). Blended teacher professional development can be both as effective and more cost effective than face-to-face, as long as the online component is clearly integrated with the face-toface component (Holmes et al., 2005; Voogt, Almekinders, van den Akker, \& Moonen, 2005).

This exploratory study is situated in Year 2 of a five-year grant project in which we will scale up our professional development to a greater number of teachers.

\section{Research Questions}

1. To what extent did a middle school teacher engage in one-to-one scaffolding during an authentic problem-based learning unit?

2. To what extent did the teacher's provision of one-to-one scaffolding vary during the unit?

3. In what other ways did the teacher support student learning during the unit?

\section{Method}

\section{Setting and Participants}

The context is a Title 1 middle school in a small rural community in the Intermountain West (USA). The school participates in a 5-year National Science Foundation (NSF) project in 
which computer-based scaffolds to help middle school students develop evidence-based arguments during PBL are developed and evaluated. Three teachers - Mr. Thomas (22 years experience), Mrs. Cooper (15 years experience), and Mrs. Carter (16 years experience; note: all names have been changed), participated in the professional development. None of these teachers had taught in a problem-based format before. As they noted, the closest they had come to teaching in an inquiry-oriented manner was having students dissect earthworms.

The principal needed to make a staffing adjustment immediately prior to the start of the school year. As a result of this, Mr. Thomas was the sole teacher in seventh grade science. Thus, we provide further detail on his prior experience here. Mr. Thomas had a considerable amount of experience (22 years) as a middle school science teacher. Based on informal observations of his teaching before undergoing the professional development, one notes that he led a very teachercentered classroom, lecturing to students, who were required to write down what he said and occasionally answer questions. In conversations with him, he confirmed that he had largely always taught in a teacher-centered manner. Thus, at the beginning of the professional development, he knew little about problem-based learning or how to facilitate it.

\section{Professional Development}

Initial face-to-face professional development. Before submitting the grant proposal, we met with the principal and the science teachers to go over the intent of our the project, which was to develop computer-based scaffolds to support middle school students' construction of evidencebased arguments during PBL. We noted that we wanted to develop the tool to work with a variety of PBL units so that teachers could develop units that center on problems that their students could perceive as authentic and which would address content standards.

Face-to-face professional development phase 1. Once funded, we met with the teachers 
and the principal for 1.5 hours to help them develop a unit that could be perceived as authentic by their students and addressed state standards with which students struggled. The teachers noted that on the State Standardized Tests, students have difficulty (a) interpreting graphs, and (b) with physical science. Physical science was not part of the 7th grade curriculum prescribed by the State, and yet many questions on the 7 th grade State Standardized Test for science covered principles of physical science. After consideration of three possibilities, we agreed that focusing on the water quality of the local river would be a potentially authentic topic since students who lived in the town and also elsewhere in the county rely on the river. This would allow students to (a) collect various data on water quality, (b) use the data to indicate what kind of water quality problems were occurring, and where, and (c) argue about how to improve water quality, and why. It would also allow for an integrated use of physical science, chemistry, and biological science. Students could also use graphs in the interpretation of the water quality data. The research team developed a working outline of the unit, and brought it back to the teachers.

Face-to-face professional development phase 2. This phase focused on unit specifics. In two 1.5 hour sessions, we met with the teachers to go over what PBL was, provide a vision of what students do in PBL, and to get the teachers' ideas for what type of learning activities (e.g., water quality data collection, guest speaker) within the broad umbrella of PBL would work. Though they were not yet expert at PBL, they were seasoned middle school science teachers who knew their students, school and community. We were able to draw on this localized knowledge in further refining the broad outline of the unit. Note: at this point we did not write lesson plans, as that was the province of the teachers. Rather, we outlined what types of activities broadly considered would happen and when, and this was done in cooperation with the teachers.

In 3 hours total of professional development, there was little chance that the teachers 
would learn everything they needed to know, but that was what that the teachers could spare during the school year. Thus we continued the professional development through online instruction during the summer, which allowed teachers to learn the material at their own pace.

Online/blended modules. The online component was delivered in the course management system Instructure Canvas (2012), and consisted of four modules:

1. PBL Module

2. Scaffolding Module

3. Brookstone River Unit Introduction

4. Brookstone River Data Collection Procedures Module (Blended module)

Each module consisted of readings, a videocast summary of the readings, a discussion, and a related assignment (e.g., lesson plan template), and was designed to take one week (10-15 hours) to complete. Within each module, teachers were directed to articulate the target knowledge and skills within the assignment, reflect on the knowledge and skills in the discussion, and provide feedback on colleagues' assignments. The research team also provided feedback on all assignments. Further detail about each module follows.

$\boldsymbol{P B L}$. The objectives of this module were that teachers be able to:

- Describe the role of students and teachers in problem-based learning

- Distinguish between problem-based learning and traditional teaching

- Describe the PBL process

- Quickly orient students to the tasks at hand and set them to work

The readings and videocast summary covered the philosophy and approach of PBL, and the role of argumentation in PBL. Teachers viewed video of science class sessions in which PBL was used, and were invited to focus on the role of teachers and students. They then compared what they saw modeled and what they read to their current classroom practices. They posted their reflections in an online discussion, and responded to the postings of their colleagues. Then, they needed to develop a lesson plan template for how they could structure a PBL class session. 
Scaffolding. At the end of this module, teachers needed to be able to:

- Describe the role of scaffolding in aiding student performance and learning

- Describe the process of providing one-to-one (teacher provided) scaffolding to students

- Describe the role of computer-based scaffolding in sharing the scaffolding role

The readings and videocast summary covered the goals, strategies, and complementary nature of computer-based and one-to-one scaffolding. The role of scaffolding in PBL as well as in supporting students' construction of evidence-based arguments was covered. Teachers viewed videos of teachers providing one-to-one scaffolding. They were invited to compare one-to-one scaffolding with their typical approaches to supporting student learning. Several strategies in one-to-one scaffolding, such as providing feedback and questioning, are also used in traditional instruction, albeit in a different form. Teachers were alerted to these differences. They posted their reflections in an online discussion, and responded to their colleagues' posting. Then, they needed to articulate in an essay how they would scaffold their students during PBL.

Brookstone river unit introduction. This module was designed to help teachers:

- Describe the intent and the process of the Brookstone river PBL unit

- Develop lesson plans to guide the facilitation of the Brookstone river PBL unit

This module was focused on (a) communicating the broad outline of the Brookstone unit and how its associated activities related to PBL, and (b) helping the teachers develop lesson plans for the unit. The readings and videocast summary covered the broad outline of the unit that the research team had developed. The discussion focused on how teachers could enlist and sustain student interest. Teachers needed to develop lesson plans for the unit, which were then reviewed by the other teachers and the research team.

Brookstone river data collection procedures (blended module). This module's objectives were that teachers be able to:

- Teach students how to complete water quality tests

- Describe to students how the tests relate to addressing the driving question of the unit 
In this module, teachers went in depth into the water quality data collection procedures. As with the online modules, the online portion of the blended module consisted of readings, a videocast summary of the readings, a discussion, and a related assignment (i.e., lesson plan for introducing water quality testing procedures), and was designed to take one week (10-15 hours) to complete. The discussion focused on how students could organize and use data both during data collection and after. Teachers needed to prepare lesson plans that would introduce the water quality data collection procedures, as well as orient students to the actual field trip in which they collected water quality data. Teachers were invited to articulate the target knowledge and skills within the lesson plan, and reflect on the knowledge and skills in the discussion.

During this module, teachers came to the university to participate in a one-day workshop in which they learned how to run water quality tests. In the first half of the workshop, facilitators introduced principles of watershed science, water quality indicators, influences on water quality, and water quality tests - dissolved oxygen, nitrates, water temperature, air temperature, turbidity, $\mathrm{pH}$, and macroinvertebrates (participants classify insects and other macroinvertibrates present in the river). In the second half, teachers went to a local river to practice the water quality tests.

Relation to theoretical framework. See Table 1 for an overview of how the design of the professional development related to characteristics of effective professional development. ---Insert Table 1---

\section{Materials}

Two class sections were randomly assigned to receive the additional support of the Connection Log, generic, computer-based scaffolds designed to support middle school students' creation of evidence-based arguments during PBL. The Connection Log encourages students to articulate answers to questions and carry out tasks individually. Articulated ideas are saved to a 
database, and can be accessed later. Groupmates can read each other's posts, ask for clarification, and come to consensus on a response to the question or task. An earlier version of the Connection Log was studied during a 7th grade unit on the Human Genome Project (Belland, 2010; Belland, Glazewski, \& Richardson, 2011); the initial version was developed based on a conceptual framework for scaffolding argumentation presented in Belland et al. (2008). In the revised version, support is arranged according to the iterative stages define problem, determine needed information, find needed information, organize information, develop claim, and link evidence to claim. At all points, students were encouraged to think from their stakeholder perspective, which they articulated in the initial stage. Furthermore, in this study, the Connection $\log$ was used in conjunction with a unit on water quality.

Along with concepts and skills from professional development, Mr. Thomas used processes promoted in the Connection Log to organize his provision of one-to-one scaffolding support. For example, he encouraged students to always think from their stakeholder perspective, and to set aside preconceived ideas about the problem. He also encouraged students to iteratively develop ideas, and to take into account input from all groupmates.

\section{Data Sources}

Data sources included (a) video observations of 3 groups of students per period, and (b) what students from these groups in experimental periods wrote in response to prompts in the Connection Log. The video observations captured teacher interactions with the selected groups. The groups (3-4 students per group) were selected to represent typical groups for the class period and, when possible, an equal number of male and female students. Video was transcribed, and we referred to the transcriptions and the video to assess teacher performance.

\section{Procedures}


Before unit start, teachers engaged in professional development, as described in the "Professional Development" section. Shortly before August, the principal needed to shuffle his teacher staff, and he made Mr. Thomas the sole teacher in 7th grade science. Mr. Thomas then completed the professional development before the unit started.

Students were assigned stakeholder positions (e.g., common citizens) and needed to (a) create a strategy to optimize the water quality of the Brookstone River, and (b) present an evidence-based argument supporting their plan. Students in two periods also had access to computer-based scaffolds to support their creation of evidence-based arguments, which were designed to supplement one-to-one scaffolding provided by the teacher. Students engaged in the unit for 14 days. On Day 1, a guest speaker spoke about the history of the Brookstone River. On Day 2, the teacher introduced the unit and what students would be doing. On Day 3, students began work in small groups. On Day 4, students collected water quality data at three points in the river. On Days 5-14, students worked in small groups. First, they (a) examined the water quality data for evidence of changes in water quality as the river proceeded through the valley, (b) researched what could cause changes in particular indicators and compared that to what is known about what happens in the Brookstone River, and (c) researched what their stakeholder group valued. They then articulated their plan to optimize the water quality, and backed it up with evidence. There was a one-week gap between the first five days and the last six days of the unit.

\section{Data Analysis}

One researcher broke the video into segments in which Mr. Thomas talked to students. A segment was defined as an episode in which Mr. Thomas talked to students and/or researchers to accomplish a certain goal (e.g., explain how to interpret the water quality data). When the goal changed (e.g., went from explaining interpretation of water quality data to telling a misbehaving 
student to pay attention), a new segment was designated. Two coders coded all video segments in which Mr. Thomas talked. For each segment, we indicated the date, time code of segment start, and time code of segment end. Then we designated each segment as:

- Whole class, one-to-one-contingent, and small group non-contingent

- Completed with or without help from the research term

- On-topic, or off topic

- Fulfilling the function of: Enlisting student interest, controlling frustration, providing feedback, indicating important task/problem elements to consider, modeling expert processes, questioning, technical troubleshooting, other lecturing

One-two sentences of notes were written on each interaction. Please note that the non-scaffolding strategies of technical troubleshooting and other lecturing could be classified as contingent if they were provided based on dynamic assessment of student understanding.

Then, the two coders met to come to consensus. To establish interrater reliability before coming to consensus, we used the Krippendorff Alpha statistic, which handles missing data and adjusts for chance in assessing agreement (Krippendorff, 2004). Before coming to consensus, we achieved the following Krippendorf alpha values, both of which represent good reliability: Type of interaction (0.84); Type of one-to-one scaffolding (e.g., modeling expert processes) (0.73).

\section{Results}

\section{The Teacher's Use of One-to-One Scaffolding}

Out of all coded interactions, $42.1 \%$ were to the whole class, and $55.3 \%$ were targeted at small groups or individual students. The remaining $2.6 \%$ were direct questions to the research team. Of the interactions that were targeted at small groups, slightly more than half $(54.8 \%)$ were contingent, and slightly less than half $(45.2 \%)$ were non-contingent. This means that, overall, when Mr. Thomas talked to small groups, he was approximately equally likely to diagnose student ability and customize his support accordingly as he was to provide support without reference to diagnosis of student ability. When considering all interactions, $30.3 \%$ were one-to- 
one scaffolding; $25 \%$ were non-contingent interactions aimed at small groups or individuals.

Of contingent interactions, the largest proportion (41.5\%) was Indicating Important Task

Elements (see Table 2). In this example of Indicating Important Task Elements, Mr. Thomas

scaffolded a group that had supported a solution based only on data collected at the river:

You based everything on our thing that we did at the river, right? We want to get some more information. For example, you might get on Google and go... 'Why are mayflies and stoneflies [two types of macroinvertibrates that are very sensitive to pollution] ... Why are they so sensitive to polluted water?' And see what it brings up, okay?

--- Insert Table 2 ---

One finding was that stoneflies, mayflies and caddisflies were prevalent near the source of the river, but were absent further south in the valley. So in this passage, Mr. Thomas was prompting the group to go beyond the raw data that was collected at the river to interpret what the lack of stoneflies, mayflies, and caddisflies indicated about the water quality of the river.

The second most common form of one-to-one scaffolding was questioning (30.4\%). It is important to note that questioning that would qualify as one-to-one scaffolding is open-ended questioning intended to make students think, including considering alternative explanations for patterns in data. As an example of questioning scaffolding, consider this exchange:

Mr. Thomas: What potential problems would you have as a Monroe (a pseudonym for the next state south of the current state) farmer or rancher from the Brookstone River?

Student 1: $\quad$ Making sure they don't use all of it.

Mr. Thomas: Okay, that is- that is one. Okay, so making sure- hoping that we'll get some water down there. Why would they care... if we used all this water? Student 3: They wouldn't have any.

Mr. Thomas: They wouldn't have any to water their crops, right? What else? What else ... would they be worried about us putting into our river?

Student 2: $\quad$ Pesticides.

Mr. Thomas: Okay. Do you think that happens?

Students: (Nod)

This group was assigned the stakeholder position of farmers in Monroe. Mr. Thomas pressed the 
group to think about the problem from the perspective of their stakeholder. In so doing, they could make better sense of the data. For example, if they think from the perspective of their stakeholder, then they would know what about the water is important to Monroe farmers.

The third most common type of one-to-one scaffolding was providing feedback $(14.7 \%)$.

In this example, Mr. Thomas talked to a student who represented common citizens and had been assigned to find "Why it is not safe for kids to be in the water." She wrote, "The kids could get cuts and stuff." She asked Mr. Thomas if what she had written was good. He responded, "And then put um, if the water's dirty...Don't worry about falling in the water, put down... they could end up drinking water that is polluted."

The student then wrote, "They [the kids] could drink water that is polluted." This shift is important because a child is not more likely to get cut in a polluted river than in a clean river. Rather, it is important to consider how coming into contact with the river water could hurt kids.

\section{Variation in the Teacher's Provision of One-to-one Scaffolding}

Variation across days. When one examines contingent one-to-one interactions as a percentage of total interactions across the unit days, it is apparent that the percentages do not hold steady (see Figure 1). The percentage of contingent interactions in all of the first five days was below the average of 30.3\%. On Day 5, Day 7, and Day 8, the magnitude of the difference exceeded one standard deviation. In five of the last six days of the unit, the percentage of contingent interactions was higher than the average: On Days 9, 11, and 13, the magnitude of difference exceeded one standard deviation. Mr. Thomas increased his use of contingent, smallgroup interaction as the unit progressed, and correspondingly decreased whole class dialogue.

---Insert Figure 1---

Almost all contingent interactions (Providing Feedback, Indicating Important Task 
Elements, Modeling Expert Processes, Questioning, Technical Troubleshooting, and Other Lecturing) increased in average occurrence over the days (See Table 3). No contingent interactions were coded as Enlisting Student Interest and only one interaction was coded as Controlling Frustration. Providing Feedback increased most, from three interactions $(M=0.6$, $S D=0.89)$ in the first five days to 29 interactions $(M=4.83, S D=2.23, E S=2.59)$ in the last six days. From the first half of the unit to the last half of the unit, Mr. Thomas' provision of contingent feedback increased on the average day by about 2.59 standard deviations. The next biggest increase was Indicating Important Task/Problem Elements, which increased by 1.88 standard deviations. Next was Questioning, which increased by 1.85 standard deviations. Other Lecturing increased by 1.47 standard deviations. Two other types of contingent scaffolding increased by less than 1 standard deviation, and Technical Troubleshooting decreased.

--- Insert Table 3 ---

Examining the different types of one-to-one interaction throughout the days, Mr. Thomas may have used strategies aligned with the students' needs of the day (See Figure 2). For example, on Day 3, Questioning (38.9\% of the interactions of the day) was the most frequent one-to-one scaffolding strategy, with Indicating Important Problem Elements shortly behind (33.3\%). However, Questioning was one of the least used scaffolding strategies on Day 8. Providing Feedback was the most common scaffolding strategy on Day 14, accounting for $66.7 \%$ of the o scaffolding interactions for the day. This makes sense, because on this day, students were rehearsing their persuasive presentations, and Mr. Thomas spent much time giving students feedback on their presentations. But on three days, Mr. Thomas did not employ Providing Feedback scaffolding at all. And on no other days did Providing Feedback constitute the most common one-to-one scaffolding strategy. Modeling expert processes was never the most 
common strategy, but it was used in five days, and was not used in six days.

---Insert Figure 2---

Variation by period/group. Examining percentages of contingent small group

interactions and non-contingent small group interaction as a percentage of total interactions, one notices that $40.9 \%$ of Mr. Thomas' interactions in Period 1 were contingent, while $19.7 \%$ of his interactions in Period 3 and $27.9 \%$ of his interactions in Period 5 were contingent.

The most frequently used types of one-to-one scaffolding were Indicating Important Task Elements (41.5\%), Questioning (30.4\%) and Providing Feedback (14.7\%). Indicating Important Task Elements was the most common, and Questioning was the second most common strategy in all 3 periods. Providing Feedback was the third most common strategy in Periods 1 and 5, while Technical Troubleshooting was the third most common in Period 3. Mr. Thomas only used Controlling Frustration scaffolding once during the whole unit.

\section{Other Ways that the Teacher Supported Student Learning}

We coded everything that Mr. Thomas said, including when he told students to shut down their computers and get ready for the bell. Mr. Thomas provided much whole class interaction $42.1 \%$ of all interactions, though the percentage decreased as the unit progressed.

Whole-class interaction. Some whole class interactions were at the beginning of class, in which Mr. Thomas would cover solutions to problems that students had the day before. For example, on Day 5, many students struggled making sense of the water quality data. At the start of period 3 on Day 6, Mr. Thomas explained to students how they should examine such:

When you're looking at... turbidity, you see what it was at Site 1, and see if it has changed from Site 2 to Site 3. If it's changed... you look over on this thing (chart indicating standards for different pollutants), and what the maximum and minimum turbidity is, and if it's...higher than that, then you have a problem, and so you go to the Connection Log and you write that the turbidity has changed... and it's going to affect my stakeholder, and you write the question down, "What can we do about it?" 
In this passage, Mr. Thomas explained how to interpret water quality data from 3 different sites. Site 1 was near the source of the river, site 2 was near the town in which the school is located, and site 3 was further south in the valley. He explained that students needed to see if turbidity is worse than the standard at any point, and how it changes as the river flows south. This passage is similar in intent to the one-to-one scaffolding strategy modeling expert processes. The difference is that it was not contingent as it was provided to the whole class.

Of the whole class interaction, the majority - $69.5 \%$ - was classified as Other Lecturing. For example, Mr. Thomas told students that mayflies will not live in the Brookstone River if it is polluted. The next largest percentage (10.9\%) was Indicating Important Task Elements. Often, this would happen when an individual student or a group would ask a question, and Mr. Thomas told the whole class to listen as he answered the question. $8.9 \%$ of whole class interactions were Off-topic or To the Researcher. Such episodes included when Mr. Thomas asked students in Period 1 whether they would be eating school lunch and when he asked the researchers how to do something in the computer-based scaffolds. Much smaller proportions were in the remaining categories: $3.3 \%$ of whole class interactions were Modeling Expert Processes, and 2.6\% were Questioning. Less than 1\% each were Enlisting Student Interest, Controlling Frustration, and Providing Feedback. That little whole class interaction focused on providing feedback makes sense because all groups were investigating different problem aspects, and would not have common answers that Mr. Thomas could assess all at once.

Non-contingent Small Group Interaction. Of the non-contingent small group interaction, 53.1\% was classified as Other Lecturing, while 19\% was Technical Troubleshooting, 15.6\% was Off Topic or to Researcher, and 6.7\% was Indicating Important Task Elements. Questioning, Providing Feedback, and Modeling Expert Processes each accounted for less than 
$4 \%$ of the non-contingent, small group interactions. No non-contingent small group interactions were classified as Enlisting Student Interest or Controlling Frustration.

Non-contingent Indicating Important Task Elements often happened when Mr. Thomas walked around the room and noticed a group engaged in irrelevant discussions or investigations. In these cases, he would simply tell students to focus on certain elements of the problem.

\section{Discussion}

\section{Relationship between Mr. Thomas' Performance and His Prior Experiences}

It would be unreasonable to expect that a teacher who taught middle school science for 22 years without ever having taught in a problem-based manner, let alone in an inquiry-oriented manner, would provide a great deal of one-to-one scaffolding right away (Lockhorst et al., 2010; Myhill \& Warren, 2005; Oliveira, 2010; van de Pol et al., 2012). Techniques introduced in teacher education can take a while to be fully implemented (Lawless \& Pellegrino, 2007; MonteSano \& Budano, 2013). Furthermore, Mr. Thomas did not know he would be teaching seventh grade science until two weeks before the start of the school year.

Mr. Thomas' lack of experience with and knowledge of problem-based learning prior to PD is congruent with the experiences and knowledge of many teachers who learn about PBL facilitation techniques (Belland, 2012; Ertmer \& Simons, 2006; Lekalakala-Mokgele, 2010). But his performance in providing one-to-one scaffolding went beyond that of many teachers in the literature. Teachers who have much experience in more teacher-directed forms of instruction often think that their prior approach worked well and that students will resist taking on more responsibility for their own learning (Goodnough \& Cashion, 2006; Stefl-Mabry, Powers, \& Doll, 2006). Many such teachers also fear giving up control in their classroom (LekalakalaMokgele, 2010). As such, professional development related to PBL facilitation techniques often 
does not impact teacher practice (Belland, 2012; Ertmer \& Simons, 2006; Pecore, 2013).

However, the results of this study indicated that Mr. Thomas performed very well in PBL facilitation. He did not use one-to-one scaffolding to the extent to be desired at the beginning of the unit. This is to be expected given that techniques introduced in professional development are usually not implemented immediately after PD (Lawless \& Pellegrino, 2007; Monte-Sano \& Budano, 2013). But the techniques were implemented after Mr. Thomas had had some practice implementing such. Thus, readers can apply lessons from the set up of the professional development to inform their own approaches to helping teachers' learning of PBL facilitation techniques. For example, comparing Mr. Thomas's experience with that of other teachers in the literature, one notes the benefit of the longer duration of the PD. This has been confirmed by extensive review work (Gerard et al., 2011). It is difficult to conceptualize how to provide such long duration PD at a reasonable cost both in terms of time, effort, and money, but also with minimal disruption to teachers' busy schedules. This study provides some insights as to how to do this. Readers can also think about new ways to look for the application of lessons learned during PD. If the teacher does not apply the target skills immediately, that does not mean that she has not learned the skills. Rather, such skills may be applied later.

\section{Mr. Thomas's Performance as Compared to Other Teachers in the Literature}

It is important to note that this study took place in a specific context. This makes it difficult to compare the experience of Mr. Thomas to that of other teachers in the literature. Yet, it is a useful exercise to see how Mr. Thomas's performance compares to that of teachers who are more experienced in providing such support. Mr. Thomas provided less whole class interaction than two out of three teachers in the van de Pol et al. (2011) study. Mr. Thomas provided one-toone scaffolding about twice as much as one of the teachers, about 1.5 times as much as another 
teacher, and a little less than the third teacher from the van de Pol et al. (2011) study. If one isolates the last six days of the unit, Mr. Thomas performed even better in comparison.

Mr. Thomas engaged in diagnosis of student reasoning at the same level as the highest performing teacher who underwent professional development on one-to-one scaffolding in van de Pol et al. (2012). This is interesting in that the teachers in the van de Pol et al. (2012) study taught at schools that emphasized self-regulated learning and cooperative learning, while Mr. Thomas had never taught in an inquiry-oriented manner. Furthermore, diagnosis of student reasoning is an aspect of one-to-one scaffolding with which teachers struggle the most (Graesser et al., 2009). One-to-one scaffolding is important not because researchers say it is, but because it has a big impact on student achievement (Ruiz-Primo \& Furtak, 2006; VanLehn, 2011).

Trends in Mr. Thomas' provision of one-to-one scaffolding echo other research. For example, van de Pol et al. (2012) found that middle school teachers' use of scaffolding strategies increased after professional development on scaffolding, but did not hold steady.

\section{What Could be Improved?}

Motivational scaffolding. One concern was Mr. Thomas's limited use of the one-to-one scaffolding strategy of Controlling Frustration, and lack of use of Enlisting Student Interest. As for whole class and non-contingent interactions, there were a total of two interactions each of Enlisting Student Interest and Controlling Frustration. It is crucial to support motivation in problem-based environments, and teachers are well-positioned to provide that support (Belland, Kim, \& Hannafin, 2013). It is not clear if the lack of motivational scaffolding by Mr. Thomas is due to a lack in the professional development program. Motivational scaffolding was covered in the professional development program, but perhaps it was not in enough depth. We could not find literature on how long it takes to develop motivational scaffolding skills through 
professional development.

Adding a module devoted to motivational scaffolding may be helpful. But as each module required the equivalent of a week's worth of work, it is unclear if adding such a module would be feasible. Teachers are busy people, and they can only devote so much time to professional development. It may be possible that with another year of experience teaching in a problem-based manner, Mr. Thomas would be able to provide better motivational scaffolding to his students. The only way to find out is through empirical research.

Variation between periods / groups. Because one-to-one scaffolding can have a big impact on student performance (Ruiz-Primo \& Furtak, 2006), it is important that all students have an equal shot at benefitting. We have every reason to believe that Mr. Thomas was equally invested in the progress of all his students, and that he did not intentionally provide less scaffolding to particular periods. One possible reason for the variation lies in the nature of oneto-one scaffolding. One-to-one scaffolding involves providing just the right amount of support at just the right time (Wood et al., 1976). If more students in a period requested Mr. Thomas's help, and he had the wherewithal to provide such help, then he would go to the students to provide contingent help more often. A second possibility is that we did not capture Mr. Thomas' provision of one-to-one scaffolding to all groups. We focused on three small groups per period. Thus, we did not videotape the 3-4 remaining small groups per period. Though we attempted to choose typical groups for each period, we could have videotaped the groups in Period 1 that needed the most help, and videotaped the groups in Periods 3 and 5 that needed the least help.

\section{Implications for Professional Development}

Flexibility. In this study, the nature of the online component allowed professional development to (a) take place in context and (b) actually happen. As noted earlier, the principal 
made Mr. Thomas the teacher of the unit just two weeks before the start of the school year due to a need to shuffle his small teaching staff. Because the online component was asynchronous, Mr. Thomas could participate in professional development when he learned this. If the professional development had been a workshop in the middle of the summer, the unit would not have been possible. This may indicate that blended learning has the potential to be more flexibly applied in such situations. Further research in other contexts is needed.

The capacity to be applied flexibly depends to a large degree on the "blend" that the professional development incorporates. Blended learning can incorporate more or less face-toface interactions than online interactions, or an equal amount (Owston et al., 2008). Furthermore, the online portion can be synchronous (e.g., video-conferencing), asynchronous (e.g., discussion and podcasts), or a combination of the two. To be most flexible, the largest portion of the professional development needs to consist of asynchronous, online interactions. But it is not clear from the literature just what the blend should be. Each of the three blended professional development programs reviewed by Owston et al. (2008) had a different blend.

Having asynchronous online professional development is not entirely unproblematic. For example, if discussions are used, teachers can contribute to the discussions whenever they are able to access the materials. But that does not mean that there will be other teachers to reply to the discussion postings, especially if these teachers finished going through the materials earlier.

Other considerations to be made when considering the blend in blended professional development include teachers' comfort with technology (Holmes et al., 2005) and evidence of impact on learning (Dede et al., 2008; Voogt et al., 2005). The creation of a community of practice whereby teachers can support each other's performance in a self-sustaining manner is not automatic (Owston et al., 2008; Voogt et al., 2005). One issue is that teachers may not be 
used to (a) interacting with other teachers asynchronously and (b) the technology involved (Owston et al., 2008). There is also some evidence that by making professional development too flexible, teachers may not participate much in online activities (Owston et al., 2008).

\section{Limitations and Suggestions for Future Research}

The principal needed to adjust staffing prior to the start of the school year. The school only had 10 teachers and covered grades 6-8. As such, ensuring that all classes were staffed with highly qualified teachers was a challenge. Because this study only describes one teacher, it is difficult to generalize to a large number of teachers. Future research should investigate the impact of professional development on a larger number of teachers.

Having two data sources is also limiting. It is thus difficult to infer what aspects of the professional development program were most beneficial such that the program can be improved, and ascertain the knowledge/skill level of participating teachers related to problem-based learning and scaffolding moves before professional development. Future research should add other data sources (e.g., interviews with and baseline observation of participating teachers). This is important to be able to attribute the use of the desired behavior (e.g., questioning) to the professional development. Also, interviews would allow one to learn which PD strategies teachers found useful and how they perceived that their practice has improved.

\section{Conclusion}

A middle school teacher with much experience teaching in a teacher-directed manner, but no prior experience teaching in a problem-based manner, provided one-to-one scaffolding at or above the level of teachers in the literature who underwent face-to-face professional development on scaffolding (Hart \& Lee, 2003; Lutz et al., 2006; van de Pol et al., 2012). More research is needed with a wider range of teachers in different contexts. This study indicates that 
such further research is warranted.

\section{Acknowledgements}

This research was supported by National Science Foundation Early CAREER Grant \# DRL-0953046 awarded to the first author. Any opinions, findings, or conclusions are those of the authors and do not necessarily reflect official positions of NSF. 


\section{References}

Abd-El-Khalick, F. (2012). Examining the sources for our understandings about science: Enduring conflations and critical issues in research on nature of science in science education. International Journal of Science Education, 34(3), 353-374. doi:10.1080/09500693.2011.629013

Abi-El-Mona, I., \& Abd $\square$ El $\square$ Khalick, F. (2011). Perceptions of the nature and "goodness" of argument among college students, science teachers, and scientists. International Journal of Science Education, 33(4), 573-605. doi:10.1080/09500691003677889

Barrows, H. S., \& Tamblyn, R. M. (1980). Problem-based learning: An approach to medical education. New York, NY, USA: Springer.

Belland, B. R. (2009). Using the theory of habitus to move beyond the study of barriers to technology integration. Computers \& Education, 52(2), 353-364.

doi:10.1016/j.compedu.2008.09.004

Belland, B. R. (2010). Portraits of middle school students constructing evidence-based arguments during problem-based learning: The impact of computer-based scaffolds. Educational Technology Research and Development, 58(3), 285-309. doi:10.1007/s11423-009-9139-4

Belland, B. R. (2012). Habitus, scaffolding, and problem-based learning: Why teachers' experiences as students matter. In S. B. Fee \& B. R. Belland (Eds.), The role of criticism in understanding problem solving: Honoring the work of John C. Belland (pp. 87-100). New York, NY, USA: Springer.

Belland, B. R. (2014). Scaffolding: Definition, current debates, and future directions. In J. M. Spector, M. D. Merrill, J. Elen, \& M. J. Bishop (Eds.), Handbook of research on 
educational communications and technology (4th ed., pp. 505-518). New York, NY, USA: Springer.

Belland, B. R., French, B. F., \& Ertmer, P. A. (2009). Validity and problem-based learning research: A review of instruments used to assess intended learning outcomes. Interdisciplinary Journal of Problem-Based Learning, 3(1), 59-89. doi:10.7771/15415015.1059

Belland, B. R., Glazewski, K. D., \& Ertmer, P. A. (2009). Inclusion and problem-based learning: Roles of students in a mixed-ability group. Research on Middle Level Education, 32(9), $1-19$.

Belland, B. R., Glazewski, K. D., \& Richardson, J. C. (2008). A scaffolding framework to support the construction of evidence-based arguments among middle school students. Educational Technology Research and Development, 56(4), 401-422. doi:10.1007/s11423-007-9074-1

Belland, B. R., Glazewski, K. D., \& Richardson, J. C. (2011). Problem-based learning and argumentation: Testing a scaffolding framework to support middle school students' creation of evidence-based arguments. Instructional Science, 39(5), 667-694. doi:10.1007/s11251-010-9148-z

Belland, B. R., Kim, C., \& Hannafin, M. (2013). A framework for designing scaffolds that improve motivation and cognition. Educational Psychologist, 48(4), 243-270. doi:10.1080/00461520.2013.838920

Bérci, M. E. (2012). The fallacies of problem-based learning viewed as in a hermeneutic perspective on best teaching practices. In S. B. Fee \& B. R. Belland (Eds.), The role of criticism in understanding problem solving: Honoring the work of John C. Belland (pp. 
161-183). New York, NY, USA: Springer.

Brand, B. R., \& Moore, S. J. (2011). Enhancing teachers’ application of inquiry $\square$ based strategies using a constructivist sociocultural professional development model. International Journal of Science Education, 33(7), 889-913. doi:10.1080/09500691003739374

Bricker, L. A., \& Bell, P. (2008). Conceptualizations of argumentation from science studies and the learning sciences and their implications for the practices of science education. Science Education, 92(3), 473-498. doi:10.1002/sce.20278

Clarke, D., \& Hollingsworth, H. (2002). Elaborating a model of teacher professional growth. Teaching and Teacher Education, 18(8), 947-967. doi:10.1016/S0742-051X(02)00053-7

Cohen, J. (1969). Statistical power analysis for the behavioral sciences. New York, NY: Academic Press.

Cohen, P. A., Kulik, J. A., \& Kulik, C.-L. C. (1982). Educational outcomes of tutoring: A metaanalysis of findings. American Educational Research Journal, 19(2), 237-248. doi:10.3102/00028312019002237

Cooner, T. S. (2010). Creating opportunities for students in large cohorts to reflect in and on practice: Lessons learnt from a formative evaluation of students' experiences of a technology-enhanced blended learning design. British Journal of Educational Technology, 41(2), 271-286. doi:10.1111/j.1467-8535.2009.00933.x

Dall'Alba, G., \& Sandberg, J. (2006). Unveiling professional development: A critical review of stage models. Review of Educational Research, 76(3), 383-412. doi:10.3102/00346543076003383

Dede, C., Jass Ketelhut, D., Whitehouse, P., Breit, L., \& McCloskey, E. M. (2008). A research agenda for online teacher professional development. Journal of Teacher Education, 
60(1), 8-19. doi:10.1177/0022487108327554

Dolmans, D. H. J. M., \& Schmidt, H. G. (2006). What do we know about cognitive and motivational effects of small group tutorials in problem-based learning? Advances in Health Sciences Education, 11(4), 321-336. doi:10.1007/s10459-006-9012-8

Elbaum, B., Vaughn, S., \& Hughes, M. T. (2000). How effective are one-to-one tutoring programs in reading for elementary students at risk for reading failure? A meta-analysis of the intervention research. Journal of Educational Psychology, 92(4), 605-619. doi:10.1037/0022-0663.92.4.605

Ertmer, P. A., \& Simons, K. D. (2006). Jumping the PBL implementation hurdle: Supporting the efforts of K-12 teachers. Interdisciplinary Journal of Problem-Based Learning, 1(1), 5. doi:10.7771/1541-5015.1005

Fessler, R., \& Rice, E. (2010). Teachers' career stages and professional development. In P. Peterson, E. Baker, \& B. McGaw (Eds.), International encyclopedia of education (pp. 582-586). Oxford, UK: Elsevier.

Frey, N., \& Fisher, D. (2010). Identifying instructional moves during guided learning. The Reading Teacher, 64(2), 84-95. doi:10.1598/RT.64.2.1

Gamble, J. A. A. (2008). A developmental evaluation primer. The J. W. McConnell Family Foundation. Retrieved from http://www.mcconnellfoundation.ca/en/resources/publication/a-developmentalevaluation-primer

Gerard, L. F., Varma, K., Corliss, S. B., \& Linn, M. C. (2011). Professional development for technology-enhanced inquiry science. Review of Educational Research, 81(3), 408-448. doi:10.3102/0034654311415121 
Gillies, R. M., \& Boyle, M. (2006). Ten Australian elementary teachers' discourse and reported pedagogical practices during cooperative learning. The Elementary School Journal, 106(5), 429-452. doi:10.1086/esj.2006.106.issue-5

Goodnough, K., \& Cashion, M. (2006). Exploring problem-based learning in the context of high school science: Design and implementation issues. School Science and Mathematics, 106(7), 280-295. doi:10.1111/j.1949-8594.2006.tb17919.x

Graesser, A. C., D’Mello, S., \& Cade, W. (2009). Instruction based on tutoring. In R. A. Mayer \& P. A. Alexander (Eds.), Handbook of research on learning and instruction (pp. 408426). New York, NY, USA: Routledge.

Grossman, P., Hammerness, K., \& McDonald, M. (2009). Redefining teaching, re $\square$ imagining teacher education. Teachers and Teaching, 15(2), 273-289.

doi:10.1080/13540600902875340

Hart, J. E., \& Lee, O. (2003). Teacher professional development to improve the science and literacy achievement of English language learners. Bilingual Research Journal, 27(3), 475-501. doi:10.1080/15235882.2003.10162604

Hmelo-Silver, C. E. (2004). Problem-based learning: What and how do students learn? Educational Psychology Review, 16(3), 235-266.

Hmelo-Silver, C. E., \& Barrows, H. S. (2006). Goals and strategies of a problem-based learning facilitator. Interdisciplinary Journal of Problem-Based Learning, 1(1), 4. doi:10.7771/1541-5015.1004

Hogan, K., \& Pressley, M. (1997). Scaffolding scientific competencies within classroom communities of inquiry. In K. Hogan \& M. Pressley (Eds.), Scaffolding student learning: Instructional approaches \& issues (pp. 74-107). Cambridge, MA, USA: Brookline. 
Holmes, A., Polhemus, L., \& Jennings, S. (2005). CATIE: A blended approach to situated professional development. Journal of Educational Computing Research, 32(4), 381-394. doi:10.2190/F97W-QUJ4-G7YG-FPXC

Hung, W. (2011). Theory to reality: a few issues in implementing problem-based learning. Educational Technology Research and Development, 59(4), 529-552. doi:10.1007/s11423-011-9198-1

Instructure Canvas. (2012). Instructure Canvas. Retrieved from http://www.instructure.com/ Jonassen, D. H. (2000). Toward a design theory of problem solving. Educational Technology Research and Development, 48(4), 63-85. doi:10.1007/BF02300500

Kaufman, R., Keller, J., \& Watkins, R. (1996). What works and what doesn't: Evaluation beyond Kirkpatrick. Performance + Instruction, 35(2), 8-12. doi:10.1002/pfi.4170350204

Kolodner, J. L., Camp, P. J., Crismond, D., Fasse, B., Gray, J., Holbrook, J., ... Ryan, M. (2003). Problem-based learning meets case-based reasoning in the middle-school science classroom: Putting Learning by Design(tm) into practice. Journal of the Learning Sciences, 12(4), 495-547. doi:10.1207/S15327809JLS1204_2

Krippendorff, K. (2004). Reliability in content analysis. Human Communication Research, 30(3), 411-433. doi:10.1111/j.1468-2958.2004.tb00738.x

Lawless, K. A., \& Pellegrino, J. W. (2007). Professional development in integrating technology into teaching and learning: Knowns, unknowns, and ways to pursue better questions and answers. Review of Educational Research, 77(4), 575-614. doi:10.3102/0034654307309921

Lekalakala-Mokgele, E. (2010). Facilitation in problem-based learning: Experiencing the locus of control. Nurse Education Today, 30(7), 638-642. doi:10.1016/j.nedt.2009.12.017 
Lindblom-Ylänne, S., Pihlajamäki, H., \& Kotkas, T. (2003). What makes a student group successful? Student-student and student-teacher interaction in a problem-based learning environment. Learning Environments Research, 6, 59-76.

doi:10.1023/A:1022963826128

Lockhorst, D., Wubbels, T., \& van Oers, B. (2010). Educational dialogues and the fostering of pupils' independence: the practices of two teachers. Journal of Curriculum Studies, 42(1), 99-121. doi:10.1080/00220270903079237

Lock, J. V. (2006). A new image: Online communities to facilitate teacher professional development. Journal of Technology and Teacher Education, 14(4), 663.

Lohman, M. C., \& Finkelstein, M. (2000). Designing groups in problem-based learning to promote problem-solving skill and self-directedness. Instructional Science, 28, 291-307. doi:10.1023/A:1003927228005

Loyens, S. M. M., Magda, J., \& Rikers, R. M. J. P. (2008). Self-directed learning in problembased learning and its relationships with self-regulated learning. Educational Psychology Review, 20(4), 411-427. doi:10.1007/s10648-008-9082-7

Lutz, S. L., Guthrie, J. T., \& Davis, M. H. (2006). Scaffolding for engagement in elementary school reading instruction. The Journal of Educational Research, 100(1), 3-20. doi:10.3200/JOER.100.1.3-20

Maloch, B. (2002). Scaffolding student talk: One teacher's role in literature discussion groups. Reading Research Quarterly, 37(1), 94-112. doi:10.1598/RRQ.37.1.4

Monte-Sano, C., \& Budano, C. (2013). Developing and enacting pedagogical content knowledge for teaching history: An exploration of two novice teachers' growth over three years. Journal of the Learning Sciences, 22(2), 171-211. doi:10.1080/10508406.2012.742016 
Mouza, C. (2009). Does research-based professional development make a difference? A longitudinal investigation of teacher learning in technology integration. The Teachers College Record, 111(5), 1195-1241.

Myhill, D., \& Warren, P. (2005). Scaffolds or straitjackets? Critical moments in classroom discourse. Educational Review, 57(1), 55-69. doi:10.1080/0013191042000274187

Oliveira, A. W. (2010). Improving teacher questioning in science inquiry discussions through professional development. Journal of Research in Science Teaching, 47(4), 422-453. doi:10.1002/tea.20345

Opfer, V. D., \& Pedder, D. (2011). Conceptualizing teacher professional learning. Review of Educational Research, 81(3), 376-407. doi:10.3102/0034654311413609

Osborne, J. (2010). Arguing to learn in science: The role of collaborative, critical discourse. Science, 328(5977), 463-466. doi:10.1126/science.1183944

Owston, R., Wideman, H., Murphy, J., \& Lupshenyuk, D. (2008). Blended teacher professional development: A synthesis of three program evaluations. The Internet and Higher Education, 11(3-4), 201-210. doi:10.1016/j.iheduc.2008.07.003

Pecore, J. L. (2013). Beyond beliefs: Teachers adapting problem-based learning to preexisting systems of practice. Interdisciplinary Journal of Problem-Based Learning, 7(2), 6-33. doi:10.7771/1541-5015.1359

Quintana, C., Reiser, B. J., Davis, E. A., Krajcik, J., Fretz, E., Duncan, R. G., ... Soloway, E. (2004). A scaffolding design framework for software to support science inquiry. Journal of the Learning Sciences, 13(3), 337-386. doi:10.1207/s15327809j1s1303_4

Raphael, L. M., Pressley, M., \& Mohan, L. (2008). Engaging instruction in middle school classrooms: An observational study of nine teachers. The Elementary School Journal, 
109(1), 61-81. doi:10.1086/592367

Rasku-Puttonen, H., Eteläpelto, A., Arvaja, M., \& Häkkinen, P. (2003). Is successful scaffolding an illusion?-Shifting patterns of responsibility and control in teacher-student interaction during a long-term learning project. Instructional Science, 31(6), 377-393.

doi:10.1023/A:1025700810376

Reiser, B. J. (2004). Scaffolding complex learning: The mechanisms of structuring and problematizing student work. Journal of the Learning Sciences, 13(3), 273-304. doi:10.1207/s15327809j1s1303_2

Rosiek, J. (2003). Emotional scaffolding: An exploration of the teacher knowledge at the intersection of student emotion and the subject matter. Journal of Teacher Education, 54(5), 399-412. doi:10.1177/0022487103257089

Ruiz-Primo, M. A., \& Furtak, E. M. (2006). Informal formative assessment and scientific inquiry: Exploring teachers' practices and student learning. Educational Assessment, 11(3-4), 205-235. doi:10.1080/10627197.2006.9652991

Sadler, T. D., Barab, S. A., \& Scott, B. (2007). What do students gain by engaging in socioscientific inquiry? Research in Science Education, 37(4), 371-391. doi:10.1007/s11165-006-9030-9

Sadler, T. D., \& Donnelly, L. A. (2006). Socioscientific argumentation: The effects of content knowledge and morality. International Journal of Science Education, 28(12), 1463-1488. doi:10.1080/09500690600708717

Schmidt, H. G., Rotgans, J. I., \& Yew, E. H. (2011). The process of problem-based learning: what works and why. Medical Education, 45(8), 792-806. doi:10.1111/j.13652923.2011.04035.x 
Shulman, L. S. (1986). Those who understand: Knowledge growth in teaching. Educational Researcher, 15(2), 4-14. doi:10.3102/0013189X015002004

Smith, C., \& Gillespie, M. (2007). Research on professional development and teacher change: Implications for adult basic education. Review of Adult Learning and Literacy, 7, 205244.

Stefl-Mabry, J., Powers, J. G., \& Doll, C. (2006). Creating and sustaining problem-based partnerships among graduate, undergraduate, and K-12 learners: Opportunities and challenges. Journal of Educational Technology Systems, 34(2), 131-153. doi:10.2190/4DMJ-85B4-GMH7-GEQB

Tan, O.-S. (2003). Problem-based learning innovation: Using problems to power learning in the 21st century. Cengage Learning Asia.

Timperley, H., \& Alton-Lee, A. (2008). Reframing teacher professional learning: An alternative policy approach to strengthening valued outcomes for diverse learners. Review of Research in Education, 32(1), 328-369. doi:10.3102/0091732X07308968

Van de Pol, J., Volman, M., \& Beishuizen, J. (2010). Scaffolding in teacher-student interaction: A decade of research. Educational Psychology Review, 22(3), 271-296. doi:10.1007/s10648-010-9127-6

Van de Pol, J., Volman, M., \& Beishuizen, J. (2011). Patterns of contingent teaching in teacherstudent interaction. Learning and Instruction, 21(1), 46-57. doi:10.1016/j.learninstruc.2009.10.004

Van de Pol, J., Volman, M., \& Beishuizen, J. (2012). Promoting teacher scaffolding in smallgroup work: A contingency perspective. Teaching and Teacher Education, 28(2), 193205. doi:10.1016/j.tate.2011.09.009 
Van Driel, J. H., Beijaard, D., \& Verloop, N. (2001). Professional development and reform in science education: The role of teachers' practical knowledge. Journal of Research in Science Teaching, 38(2), 137-158. doi:10.1002/1098-2736(200102)38:2<137::AIDTEA1001>3.0.CO;2-U

VanLehn, K. (2011). The relative effectiveness of human tutoring, intelligent tutoring systems, and other tutoring systems. Educational Psychologist, 46(4), 197-221. doi:10.1080/00461520.2011.611369

Voogt, J., Almekinders, M., van den Akker, J., \& Moonen, B. (2005). A “blended” in-service arrangement for classroom technology integration: impacts on teachers and students. Computers in Human Behavior, 21(3), 523-539. doi:10.1016/j.chb.2004.10.003

Wayne, A. J., Yoon, K. S., Zhu, P., Cronen, S., \& Garet, M. S. (2008). Experimenting with teacher professional development: Motives and methods. Educational Researcher, 37(8), 469-479. doi:10.3102/0013189X08327154

Webster-Wright, A. (2009). Reframing professional development through understanding authentic professional learning. Review of Educational Research, 79(2), 702-739. doi:10.3102/0034654308330970

Wood, D. (2003). The Why? What? When? and How? of Tutoring: The development of helping and tutoring skills in children. Literacy Teaching and Learning, 7(1), 1-30.

Wood, D., Bruner, J. S., \& Ross, G. (1976). The role of tutoring in problem solving. Journal of Child Psychology and Psychiatry, 17(2), 89-100. doi:10.1111/j.14697610.1976.tb00381.x

Yoon, K. S., Duncan, T., Lee, S. W.-Y., Scarloss, B., \& Shapley, K. L. (2007). Reviewing the evidence on how teacher professional development affects student achievement. Issues \& 
answers (Eric Document No. ED498548). Regional Educational Laboratory Southwest.

Retrieved from

http://www.eric.ed.gov/ERICWebPortal/contentdelivery/servlet/ERICServlet?accno=ED 498548 
Teacher Learning to Provide One-to-One Scaffolding 42

Tables 
Table 1. How the design of the professional development aligns with identified best practices for professional development.

\begin{tabular}{|c|c|c|c|c|c|}
\hline \multicolumn{2}{|c|}{ Face-to-Face } & \multicolumn{3}{|c|}{ Online Modules } & \multirow{2}{*}{\begin{tabular}{l}
\multicolumn{1}{c}{ Blended Module } \\
Brookstone River \\
Data Collection \\
Procedures
\end{tabular}} \\
\hline $\begin{array}{l}\text { Face-to-face PD } \\
\text { Phase } 1\end{array}$ & $\begin{array}{l}\text { Face-to-face PD } \\
\text { Phase } 2\end{array}$ & PBL Module & Scaffolding Module & $\begin{array}{l}\text { Brookstone River } \\
\text { Unit Introduction }\end{array}$ & \\
\hline
\end{tabular}

Characteristics of

Effective

Professional

The total contact hours of the professional development was 43-63 hours, and was spread over 6 weeks

Duration should be

long and sustained

PD should be taught in context

In negotiating unit content, we took

into account school

and community

Teachers need to use PD content during PD

Teachers articulated

(a) areas of

difficulty of

students on state

standards tests and

(b) thoughts on

relevant problems to

be investigated

Peer learning should

be encouraged

In negotiating unit activities, we took

into account school

and community

culture

$\begin{array}{ll}\text { Teachers viewed } & \begin{array}{l}\text { Teachers viewed } \\ \text { videos of }\end{array}\end{array}$

comparable science science teachers

classrooms in which who provided one-

PBL was used to-one scaffolding

Teachers articulated Teachers created a Teachers articulated ideas for specific

instructional

activities within the

PBL unit

lesson plan template

for use during PBL

lessons

how they would

scaffold student

learning during the unit

\section{Teachers (a)}

engaged in online

engaged in online

discussion on PBL,

and (b) peer

reviewed each

other's lesson plans
The unit topic

local importance

learned the

procedures at a real

river

Teachers developed Teachers developed

lesson plans for lesson plans for

individual days introducing the

during the unit

water quality test

procedures to

student

$\begin{array}{ll}\text { Teachers (a) } & \text { Teachers (a) } \\ \text { engaged in online } & \text { engaged in online } \\ \text { discussion on } & \begin{array}{l}\text { discussion on how } \\ \text { students could }\end{array} \\ \text { enlisting and } & \text { organize and use } \\ \text { sustaining student } & \text { data, and (b) peer } \\ \text { interest, and (b) peer } & \text { reviewed each } \\ \text { reviewed each } & \text { other's lesson plans } \\ \text { other's lesson plans }\end{array}$

discussion on

scaffolding, and (b)

peer reviewed each

other's scaffolding

essays 
Table 2. Types of one-to-one scaffolding provided by Mr. Thomas.

\begin{tabular}{lcc}
\hline \multicolumn{1}{c}{ Type of One-to-One Scaffolding } & $\begin{array}{c}\text { Number of } \\
\text { Instances }\end{array}$ & $\begin{array}{l}\% \text { of Total Contingent } \\
\text { Interactions }\end{array}$ \\
\hline Enlisting student interest & 0 & $0 \%$ \\
Controlling frustration & 1 & $0.5 \%$ \\
Providing feedback & 32 & $14.7 \%$ \\
Indicating important task elements to consider & 90 & $41.5 \%$ \\
Modeling expert processes & 8 & $3.7 \%$ \\
Questioning & 66 & $30.4 \%$ \\
Technical troubleshooting & 12 & $5.5 \%$ \\
Other lecturing & 8 & $3.7 \%$ \\
\hline Total & 217 & $100 \%$ \\
\hline
\end{tabular}


Teacher Learning to Provide One-to-One Scaffolding 45

Table 3. Total incidences, average incidences per day, and standard deviation for each type of contingent interaction provided by Mr. Thomas in the first five days, the last six days, and the entire unit. Enlisting Interest was not included because no contingent interactions were rated as Enlisting Interest.

\begin{tabular}{lccccccc} 
& \multicolumn{2}{c}{ First 5 days } & \multicolumn{2}{c}{ Last 6 Days } & \multicolumn{2}{c}{ Entire Unit } \\
\cline { 1 - 5 } Contingent Interaction & $\mathrm{N}$ & $\mathrm{M}(\mathrm{SD})$ & $\mathrm{N}$ & $\mathrm{M}(\mathrm{SD})$ & $\mathrm{N}$ & $\mathrm{M}(\mathrm{SD})$ & $d$ \\
\hline Controlling Frustration & 0 & $0(0)$ & 1 & $0.17(0.41)$ & 1 & $0.09(0.3)$ & 0.57 \\
Providing Feedback & 3 & $0.6(0.89)$ & 29 & $4.83(2.23)$ & 32 & $2.91(2.77)$ & 2.59 \\
Indicating Imp. Task Elements & 22 & $4.4(1.14)$ & 68 & $11.33(5.96)$ & 90 & $8.18(5.6)$ & 1.88 \\
Modeling Expert Processes & 3 & $0.6(0.89)$ & 5 & $0.83(1.17)$ & 8 & $0.73(1.01)$ & 0.32 \\
Questioning & 19 & $3.8(2.68)$ & 47 & $7.83(3.37)$ & 66 & $6.0(3.61)$ & 1.85 \\
Technical Troubleshooting & 6 & $1.2(1.3)$ & 6 & $1.0(1.1)$ & 12 & $1.09(1.14)$ & -0.25 \\
Other Lecturing & 0 & $0(0)$ & 8 & $1.3(1.21)$ & 8 & $0.73(1.10)$ & 1.47 \\
\hline
\end{tabular}




\section{Figures}

Figure 1. Contingent interactions, as a percentage of total interactions for each day.

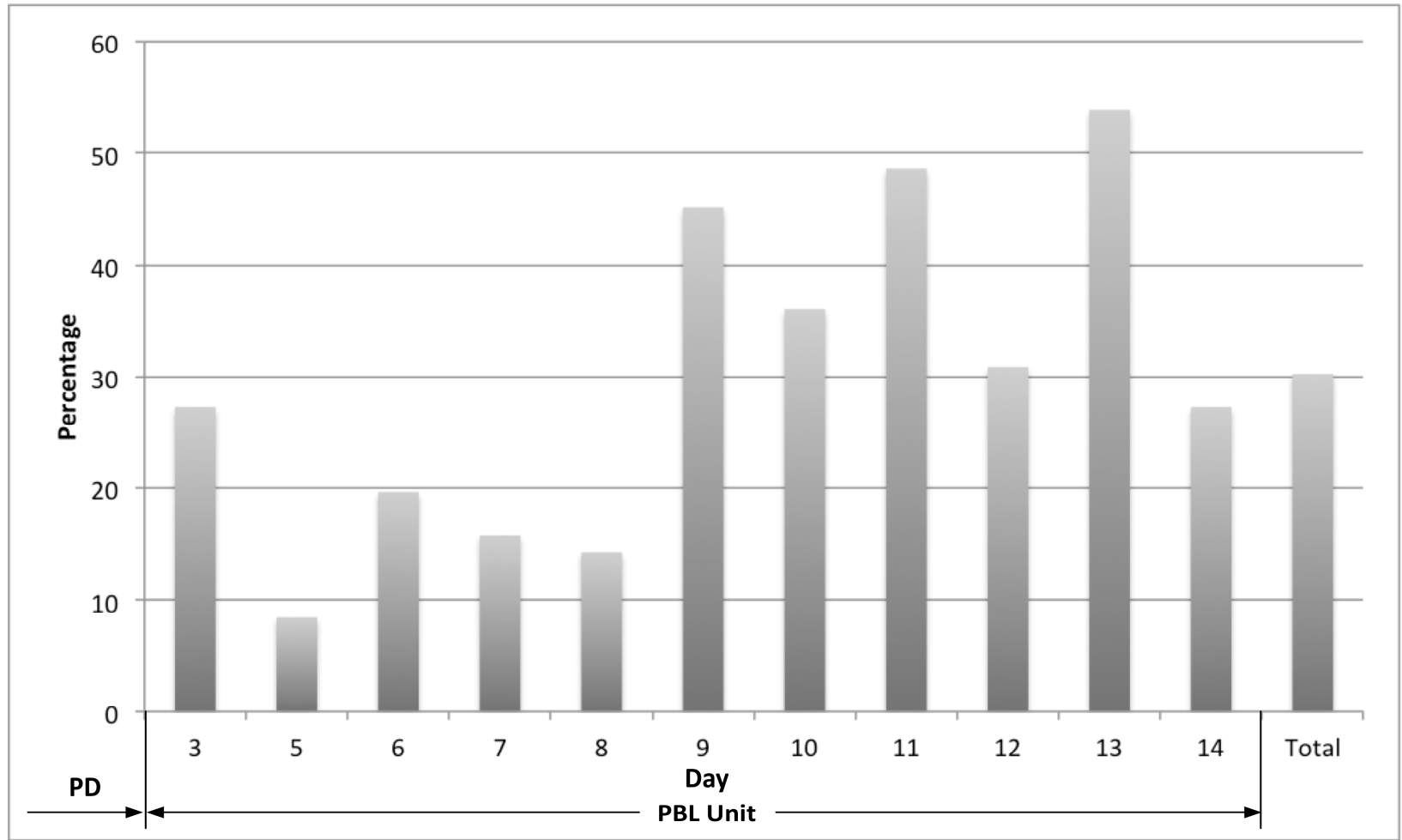


Figure 2. Different types of Contingent Interactions as a percentage of total Contingent Scaffolding Episodes by day.

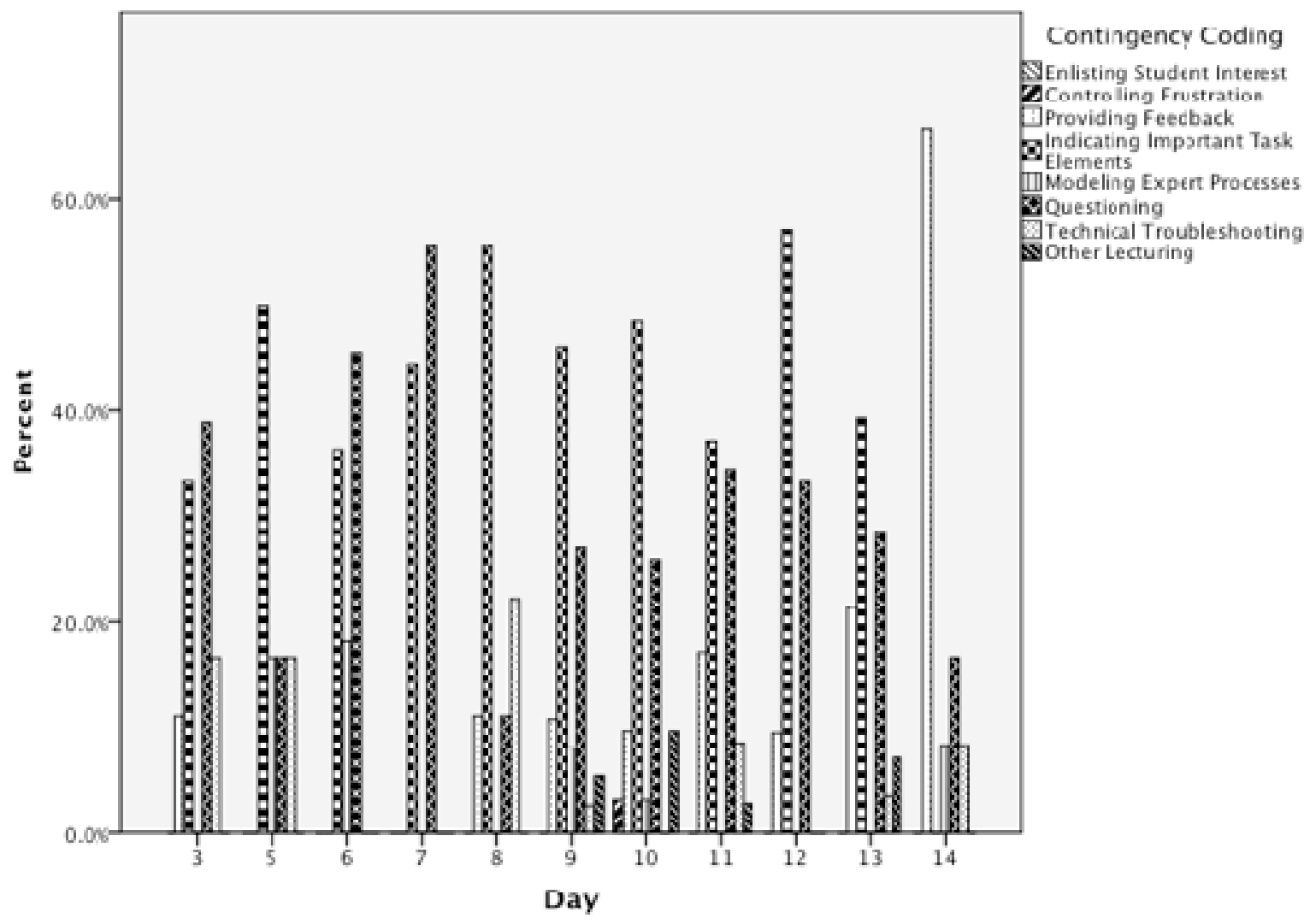

